\title{
Comparing the Role of the Outsider in Beowulf and Marie de France's Lanval
}

\section{Courtney Krentz}

The character of the outsider can be identified in a diverse range of medieval works, including the Old English heroic epic and the Middle English lai. Indeed, both Beowulf and Marie de France's Lanval prominently feature characters who are outsiders, although these characters are presented quite differently within each work. In Beowulf, the characters of Grendel and his mother are outsiders with respect to the heroic society of Beowulf and his kingdom, and in Lanval, Marie de France's titular character begins his lai in a melancholic state as he struggles to understand why his king neglects him and favours the other retainers. While both of these works feature outsiders, the reasons why they are outcast from their respective societies are quite different. Grendel and his mother are outcast because they are descendants of Cain, whose bloodline God condemned after Cain killed his brother Abel. As a method of taking vengeance for his exclusion, Grendel attacks the court of King Hrothgar every night for many years, killing as many of Hrothgar's loyal retainers as he possibly can. Conversely, Marie de France does not suggest that Lanval bears any similar condemnation; instead, she indicates that he is unjustly cut from society because his king forgets him, and the other retainers are jealous of him. Despite these differences between Grendel and Lanval, both characters function to comment upon the nature of their respective civilizations; however, where Grendel effectively reaffirms the importance of the hall and the king's relationship with his retainers, Lanval does the opposite and instead serves to question whether life in King Arthur's court actually benefits those who live within it.

The relationship between the king and his retainers - or the comitatus, as it is referred to in Old English literature such as Beowulf - is one of the most important and commonly occurring examples of civilization in medieval literature. Both Beowulf and Lanval comment on the importance of this relationship by contrasting those who are within the comitatus, and thus benefit from the relationship, with those who are outside it. Within the comitatus, the king is expected to share his resources with his retainers and provide them with a place to live. In return for the king's generosity, his retainers provide unwavering loyalty and will fight to the death for him if necessary. Beowulfs speaker highlights the importance of the comitatus to the epic's kingdoms right from the opening lines, as he discusses the kings who ruled the Danes prior to Hrothgar. When discussing Scyld Scefing, for instance, the speaker emphasizes that this king "grew under heaven and prospered in honor" (8) and refers to him as a "dispenser of rings" (35), indicating the importance of acting honorably and distributing one's wealth. Indeed, as the epic progresses, the speaker suggests that both Hrothgar and Beowulf are considered good kings in part because of their eagerness to share their wealth with their retainers. As such, the kingdoms of Beowulf begin to represent sites of civilization, where "the hall in the poem serves as a symbol of peace on earth and good will toward men, marked by the... activities of giving and feasting" (Schichler 100). By emphasizing this strong unit of civilization within the hall, the speaker effectively establishes the basis for Grendel's introduction as a monstrous entity fully apart from civilization.

Vol. 4(1) | DOI: https://doi.org/10.31542/muse.v4i1.1852 


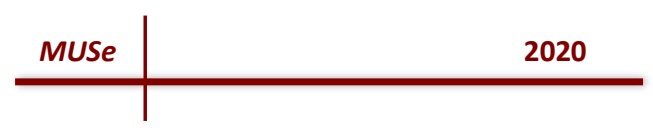

Grendel's distance from the civilization within Hrothgar's hall of Heorot is immediately apparent as his character is introduced. Grendel begins the epic sitting on the fringes of Heorot, where he can hear the "joyful din / loud in the hall, with the harp's sound, / the clear song of the scop" (88-90). As Grendel listens to the scop's song about God's creation of the world, his anger grows. Throughout this scene, the speaker describes him as an "unholy creature, / grim and ravenous" (120-121), suggesting that Grendel is more monster than human. This description thus emphasizes Grendel's distance from the civilization within Heorot and ensures that the reader is aware of Grendel's status as an evil intrusion upon the hall. As Schichler notes, Grendel is "a killer, a demon.... a damned descendent of Cain for whom there is no hope of redemption and for whom the poet will allow no pity" (101), and because the speaker makes it clear that we are not to pity Grendel, his status as this monstrous outsider reaffirms the righteousness of Heorot and those who live within it.

In Lanval, however, Marie de France does not suggest that Lanval is in any way murderous or otherwise deserving of his being outcast from the hall, as Grendel is; on the contrary, Lanval maintains a reputation as a "very noble vassal" (4) within King Arthur's court. Indeed, Marie de France ensures that the reader knows that Lanval was unjustly cut from this courtly society, as she indicates that Arthur "shared out wives and land / among all except one who had served him: / that was Lanval, whom he does not remember" (17-19). Further, Marie de France notes that the other vassals in Arthur's court were jealous of Lanval's "valor, his generosity / his beauty, [and] his prowess," (21-22), to the extent that they would have been glad if something bad happened to him. The feudal system that was in place during Marie de France's writing was not quite the same as the kingdoms of Beowulf, where the giving and sharing of gifts by kings is customary. However, the feudal system expects that when vassals like Lanval are providing military service to a lord such as King Arthur, their service is recognized as part of a "reciprocal system of land tenure and feudal service" (Rouse 13). This disparity between the expectations of the feudal system and how the system actually functions in Lanval "reveals [the system's] precarious foundation" (Kick 94). Thus, where Grendel's introduction serves to reaffirm the hall as a place of civilization and comradery, the initial lines of Lanval question whether the system of King Arthur's court was actually benefiting those who lived within it.

As Lanval progresses, Marie de France indicates that this questioning of Arthur's court is valid, being that it becomes "necessary for Lanval to visit another court for the [courtly] code of behaviour to work for him" (Doggett 236). Dejected and worried about his difficult situation, Lanval rides his horse out to a meadow to be alone. Before long, Lanval is approached by two maidens who bring him to Avalon and introduce him to their queen, who is so beautiful that she "surpasse[s] in beauty / the lily or the new rose / when it appears in summer" (94-96). This fairy queen and Lanval become lovers, under her condition that he may not tell anyone about her existence. Interestingly, the fairy queen's court appears to mirror the type of civilization that exists at Arthur's court, but while Lanval's "courtesy [and] promise of loyalty" (Doggett 237) are reviled at Arthur's court, they are celebrated in the court of his fairy mistress. In return for his loyalty and promise not to reveal her, the fairy queen informs Lanval that he can call upon her whenever he needs her and gives him riches enough that he can "give and spend generously" (138) without fear of ever being poor. When Lanval returns to King Arthur's court, he takes great joy in bestowing his gifts upon all of the inhabitants of the court, despite the fact that they have 


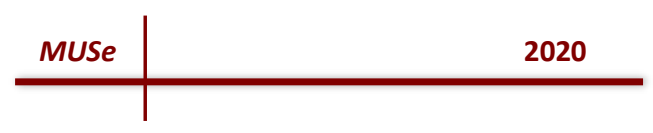

never shared their wealth with him. Although he is still something of an outsider, Lanval maintains an attitude of chivalry towards the other vassals and continues to try to fulfill a position within this courtly society even though it has not helped him in return.

Grendel's reaction to being outcast from society is quite different from Lanval's, but while Marie de France questions the system of Arthur's court, Beowulfs speaker uses Grendel to continually reaffirm the importance of the hall and the comitatus to Beowulfs heroic warrior society. While Lanval maintains his loyalty to King Arthur's court and is happy to distribute the wealth of the fairy queen, Grendel is overcome with murderous rage at hearing the song of the scop. He attacks Heorot, and "[takes] from their rest / thirty thanes... / rejoicing in his booty" (122-124). This attack is not a one-time occurrence, either - Grendel returns every night for "twelve long winters" (147) to kill as many of Hrothgar's men as possible. Beowulfs speaker indicates that this needless murder would have continued forever if not for Beowulf's intervention, as Grendel "wanted no peace / with any man of Danish army" (154-155). Throughout Grendel's reign of terror over Hrothgar's retainers, the speaker makes it clear that it "does not matter that Grendel feels pain, and that his actions stem from pain and exclusion" (Schichler 102). On the contrary, Grendel constitutes "a threat to all civilization" (Classen 525), and because the speaker continues to emphasize this point, he ensures that the reader does not pity or identify with Grendel, but instead pities Hrothgar and his thanes, who are needlessly attacked and killed.

While these characters' reactions to their exclusion from society indicate how the reader is meant to respond to them, their function within their respective works is clarified further by what happens to them at their stories' conclusions. At this point in the epic of Beowulf, it is clear that Grendel represents violent evil at its worst, and that he is not to be pitied; however, Beowulfs speaker emphasizes this fact further when describing Grendel and his mother's home. After fighting with Beowulf, Grendel's arm is ripped from its socket, and he flees from the hall to die in his lair. When Beowulf and his men approach the lair to fight his mother, they take note of the "murky land / ... wolf haunted slopes, [and] windy headlands" (1356-1357) that surround the area. The lair itself, which is beneath a lake, is guarded by "fire on the water" (1366), and the speaker indicates that the strongest of soldiers would "sooner lose / his life on the shore than save his head / and go in the lake" (1370-1372). These remarks suggest that facing the monsters that lie on the fringes of the lair would be preferable to facing Grendel and his mother, and thus indicate the level of monstrosity and evil that these beings embody. Beowulf enters the lair and kills Grendel's mother, but on his way out, he notices Grendel "lying lifeless, / battle-weary from the wound he received / in the combat at Heorot" (1586-1588) and decides to cut off his head and bring it to shore as a trophy. Despite the gruesome nature of such a trophy, the speaker does not indicate that the reader should be repulsed by Beowulf's actions, but instead suggests that they should celebrate the vanquishing of this evil that has terrorized the civilization of Heorot for so long. Schichler suggests that Beowulfs speaker "uses Grendel to scare his audience... so that they distance themselves from what Grendel represents: sin, error, the Satan principle of the human psyche" (101-102). By repeatedly stressing the evil of Grendel's actions, Beowulfs speaker does seem to become almost didactic in this way, warning readers against the potential consequences of acting as Grendel, while reaffirming the actions of those within the civilization of the kingdom. 
Where Grendel's story ends with his death and the mutilation of his body, Lanval's ends on quite an opposite note, with him escaping King Arthur's court and leaving for Avalon with the fairy queen. Before this can occur, though, Lanval faces even further exclusion from Arthur's court, as Arthur's queen notices his new wealth and clothing and propositions him. Refusing to betray both Arthur and his fairy mistress, Lanval declines, revealing his mistress and breaking his promise in the process. Arthur's queen is furious and tells Arthur that Lanval "insulted her and said ugly things" (319), and, as a means of standing up for himself and his wife, Arthur puts Lanval to trial. Eventually, the fairy queen arrives at the trial with a few of her maidens, and those who saw her arrive "considered it a great marvel; / there was not one who looked at her / who did not grow warm with true joy" (582-584). Her beauty and courtliness are so stunning that everyone present "understand[s] immediately and without protest that the beauty, fine apparel, refinement, and courtesy of the ladies far exceed those of Arthur's court and so the king defers to them" (Doggett 238) and allows Lanval to leave without protest. In these scenes, Marie de France seems to confirm any question the reader may have had about the nature of life at King Arthur's court, as it is clear that Arthur's court pales in comparison to that of the fairy queen.

Thus, where Grendel functions within the epic of Beowulf to reaffirm the importance of the civilization of the king's hall, the character of Lanval does quite the opposite, and instead serves to question the nature of the civilization of Arthur's court. Throughout Beowulf, the speaker ensures that the reader feels no pity for Grendel, and in doing so, he highlights the righteousness of those who live within Heorot and maintain a position within the comitatus. Conversely, in Lanval, Marie de France suggests that life at Arthur's court, and perhaps within the feudal system more broadly, did not benefit the vassals in the way that it should have. While these characters function within their works in quite different ways, both of these outsiders effectively comment upon the nature of life in a king's court during their respective time periods. 


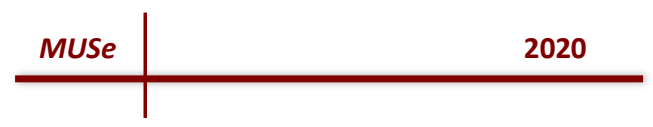

\section{References}

Classen, Albrecht. "The Monster Outside and Within: Medieval Literary Reflections on Ethical Epistemology. From Beowulf to Marie de France, the Nibelungenlied, and Thuring von Ringoltingen's Melusine." Neohelicon: Acta Comparationis Litterarum Universarum, vol. 40, no. 2, 2013, pp. 521-542.

de France, Marie. "Lanval." Translated by Claire M. Waters. The Broadview Anthology of British

Literature: The Medieval Period, edited by Joseph Black et al., 3rd ed., vol. 1, Broadview Press, 2015, pp. 219-233.

Doggett, Laine. "The Favorable Receptions of Outsiders at Court: Medieval Versions of Cultural Exchange." Shaping Courtliness in Medieval France: Essays in Honour of Matilda Tomaryn Bruckner, edited by Daniel O'Sullivan and Laurie Shephard, D. S. Brewer, 2013, pp. 229-239.

Kick, Linda. "Marie de France: Inclusion of the Outsider." The Image of the Outsider in Literature, Media, and Society, edited by Will Wright and Steven Caplan, Colorado UP, 2015, pp. 93-96.

Liuzza, R. M., translator. Beowulf. The Broadview Anthology of British Literature: The Medieval Period, edited by Joseph Black et al., 3rd ed., vol. 1, Broadview Press, 2015, pp. 69-116.

Rouse, Robert. "Historical Context: The Middle Ages and the Code of Chivalry." Handbook of Arthurian Literature, edited by Leah Tether and Johnny McFayden, De Gruyter, 2017, 13-24.

Schichler, Robert L. "Understanding the Outsider: Grendel, Geisel, and the Grinch." Popular Culture Review, vol. 11, no. 1, 2000, pp. 99-105. 